\title{
LOKÁLIS ENERGIAFORRÁSOK TÁVHŐ CÉLÚ FELHASZNÁLÁSI LEHETŐSÉGÉNEK VIZSGÁLATA
}

\section{STUDY OF THE POSSIBLE USES OF LOCAL ENERGY HEAT SOURCES IN DISTRICT HEATING}

\author{
Göblyös Béla ${ }^{1}$, Réger Mihály ${ }^{2}$ \\ ${ }^{I}$ Dunaújvárosi Viz-, Csatorna- Höszolgáltató Kft., Cím: Magyarország, Dunaújvá- \\ ros, Épitők útja1,bgoblyos@alfanova.hu \\ ${ }^{2}$ Óbudai Egyetem, 1034 Budapest, Bécsi út 96/B,reger.mihaly@bgk.uni-obuda.hu
}

\begin{abstract}
There are a plenty of studies and theories regarding the global warming and the related extenuation of fossil fuel both being the most important problem of the future of the mankind. The melting of high alpine glaciers and polar ice shelves, the decreasing area of permafrost, the increased emission of the industry and the rapid overpopulation show that the problem is real and needs quick and effective intervention. This paper is studying the possible uses of local heat sources in the district heating sector.
\end{abstract}

Keywords: district heating, local heat sources, wastewater sludge, municipal waste.

\section{Összefoglalás}

A globális felmelegedéssel és az ezzel összefüggő fosszilis energiahordozók kimerülésével - mint az emberiség jövőjével kapcsolatos két legfontosabb problémájával - kapcsolatban rengeteg tanulmány és találgatás jelent meg. A magashegységi gleccserek és a sarki jégtakaró olvadása, a permafrost területek csökkenése, az ipari termelés okozta kibocsátás növekedés, a Föld lakosságának rendkívül gyors gyarapodása, stb. mind azt mutatják, hogy a probléma valós és rendkívül gyors és hatékony beavatkozást igényel. A dolgozat a lokális energiaforrások távhő célú felhasználási lehetőségét vizsgálja.

Kulcsszavak: távfütés, helyi energiaforrás, szennyviziszap, kommunális hulladék.

\section{Bevezetés}

$\mathrm{Az}$ ipari forradalom óta ugrásszerüen növekvő népesség, az urbanizáció és az ipari termelés növekedése velejáró következménye a fosszilis energiahordozók növekedő arányú felhasználása.

Előzők alapján belátható, hogy a véges mennyiségben rendelkezésünkre álló fosszilis energiák kimerülésére mindenképpen számítanunk kell, az egyes modellek csak a bekövetkezés időpontjában térnek el, abban egységesek, hogy a fosszilis energiahordozók kimerülnek.

Az elérendő cél tehát kettős:

- egyrészt a még meglévő készleteket a lehető legjobb hatásfokkal kell kiaknázni és felhasználni, a meglévő eljárások tökéletesítésével és új eljárások megalkotásával,

- másrészt viszont olyan energiapolitikai megfontolásokat kell tennünk, melyben a megújuló energia egyre nagyobb részt tölt be. Távlati célként a teljes energia- 
igényt megújuló forrásból kell előállítani.

\section{A hőelőállítási források priori- tása}

A távfütéshez szükséges hő elöállítása több forrásból is történhet. Az egyes források nem azonos mennyiségben, minőségben állnak rendelkezésre, így célszerü az egyes források felhasználásának prioritási sorrendjét meghatározni.

Mivel a távhő előállításától függetlenül is keletkezik a településen kommunális hulladék és szennyvíz, melyek megfelelő ártalmatlanításáról és elhelyezéséről gondoskodni kell, így ezek energetikai hasznosítása rendkívül előnyösnek tünik, hiszen optimális esetben az ártalmatlanítási és az energetikai célú hasznosítási folyamat egymást átfedi. Fentiek miatt a távfütési célú hő előállítása során az ilyen módszerek prioritást élveznek. Az e módon előállított hőt $Q_{h e l y i}^{1}$ néven fogjuk jelölni, ebbe tartozik a szennyvízből és a települési hulladékból nyerhető hő, azaz $\left(Q_{\text {helyi }}^{1}=\right.$ $Q_{\text {szennyvíz }}+Q_{\text {szemét }}$ ). Amely településen távhőigény merül fel, ott szemét és szennyvíz is keletkezik, tehát az energiahordozók ezen köre minden esetben rendelkezésre áll. Elsőbbséget élveznek továbbá az egyéb településen lévő ipari létesítmények technológia hőforrásai is, hiszen ezekben is hö keletkezik, melynek elsődleges célja nem a távfütés, hanem jellemzően az ipari folyamatok (acélgyártás, müanyaggyártás, sörfőzde, stb.) kiszolgálása. Ezeket a továbbiakban $Q_{\text {helyi-vel jelöljük. A technológia }}^{2}$ felhasználású hő azonban sok esetben még tartalmaz annyi energiát, ami a távfütésben felhasználható. A technológiai hő (melyet többnyire hulladékhőnek neveznek) azonban kétélü fegyver, mert a távhő ellátás ez esetben az ipari üzemtől függ, annak megszünése akár a távhőellátás megszünéséhez is vezethet [1].
Amennyiben a fenti hőforrásokat már kiaknáztuk, akkor kerülhet sor a megújuló energiaforrások alkalmazására $\left(Q_{\text {helyi }}^{3}=\right.$ $\left.Q_{m e g u ́ j u l o ́}\right)$ a helyi adottságokat figyelembe véve, és csak az ezen energiaforrások felhasználása után fennmaradó hőigényt kell primer energiahordozó (földgáz, kőolaj, pakura, szén, stb). eltüzelésével biztosítani $\left(Q_{\text {helyi }}^{4}\right)$.

\section{Hőtermelés kommunális hulla- dékból}

A kommunális hulladékból két módszerrel állíthatunk elö höt: a szemét közvetlen elégetésével és/vagy a szemétből fejlödő gáz elégetésével

Mivel a kommunális hulladék alkotóelemei közül a fenti két eljárás alapanyai átfedést mutathatnak így a hulladék átválogatását ezen szempontok szerint is optimalizálni kell. Az energetikai célú hasznosításhoz szükségünk van még a hulladék fütőértékére, melynek meghatározása mivel a kommunális hulladék inhomogén és változó összetételü - bonyolult feladat. A begyüjtött hulladékból égetéssel kinyerhetö elméleti hőmennyiség az alábbi:

$$
Q_{\text {hulladék }}=\sum_{i=1}^{n}\left(m_{i} \cdot H_{\text {inf }, i}\right)
$$

ahol, $\mathrm{m}_{\mathrm{i}}=$ az egyes összetevők tömege, $\mathrm{H}_{\mathrm{inf}}$, $\mathrm{i}=$ az egyes összetevők alsó fütőértéke.

\section{Hőtermelés szennyvízből}

A szennyvízben lévő energiatartalom kiaknázása kétféle módon történhet:

1. a szennyvíz szerves anyag tartalmának felhasználásával

a. a keletkező iszap közvetlen eltüzelésével, és/vagy

b. a keletkező iszap elrothasztásával keletkező gázok elégetésével

2. a szennyvíz hőtartalmának hasznosításával 


\subsection{A keletkező iszap közvetlen ener- getikai hasznosítása}

A szennyvíztisztítás során keletkező és a folyamatból elvett ún. fölös iszapnak az energetikai hasznosítás elött - hogy az önfenntartó égés fizikai paramétereit biztosítani lehessen - előkezelésen kell átesnie. Az előkezelés során az alábbi feltételeknek megfelelö szennyvíziszapot kell végeredményként kapni [2]:

$$
\begin{aligned}
& \text { nedvességtartalom }<50 \%, \\
& \text { hamutartalom }<60 \%, \\
& \text { szerves anyag tartalom }<25 \%
\end{aligned}
$$

Sajnos ezek az értékek csak jelentős többletenergia és többletköltséggel érhetőek el, így az energetikai célú hasznosításkor célszerü az iszapot a települési hulladékhoz keverve elégetni. Egy település szennyvízéből keletkező fölös eleven iszap égetésével kinyerhető hő elméleti értéke az alábbi módon számolható:

$$
Q_{\text {szennyvíziszap }}=m_{\text {iszap }} \cdot H_{\text {iszap }}
$$

ahol, a $\mathrm{m}_{\text {iszap }}$ az évente keletkező iszap mennyisége [kg], $\mathrm{H}_{\text {iszap }}$ : az iszap fütőértéke $[\mathrm{MJ} / \mathrm{kg}]$.

\subsection{A keletkező iszap elrothasztásával keletkező gázok hasznosítása}

Ebben az esetben a szennyvíztisztás során keletkező iszap a rothasztóba kerül, ahol az iszap szerves anyag tartalma anaerob (azaz oxigén jelenléte nélkül) rothasztás során metánná $\left(\mathrm{CH}_{4}\right)$ és szén-dioxiddá $\left(\mathrm{CO}_{2}\right)$ azaz biogázzá alakul át. A keletkező biogáz mennyiségének becslése legegyszerübben a kémiai oxigénigény (KOI) változásával történhet. Mivel a KOI az anaerob rothasztásnál állandó mennyiség, így a rothasztóba érkező KOI értéke megegyezik a rothasztóból távozó KOI értékével (lévén, hogy nem történik oxidáció), azaz a rendszerbe érkező szerves anyagból eltávolított
KOI szükségképpen egyenlő a vizes fázissal távozó KOI $\left(\mathrm{KOI}_{\mathrm{ki}}\right)$ és a keletkező biogáz KOI egyenértékének $\left(\mathrm{KOI}_{\text {biogáz }}\right)$ az összegével.

$K O I_{b e}=K O I_{k i}+K O I_{\text {biogáz }} \rightarrow K O I_{\text {biogáz }}=$

$K O I_{b e}-K O I_{k i}$

Mivel a $\mathrm{CO}_{2} \mathrm{KOI}$ értéke nulla, így a $\mathrm{KOI}_{\text {biogáz }}$ értéke csakis a metánra $\left(\mathrm{CH}_{4}\right)$ vonatkozik. Mivel a KOI mérése mind a belépő $\left(\mathrm{KOI}_{\mathrm{be}}\right)$, mint pedig a kilépő ponton $\left(\mathrm{KOI}_{\mathrm{ki}}\right)$ mérve van - hiszen ezen paraméterre jogszabály határértéket ír elő - a keletkező biogáz mennyisége viszonylag egyszerüen számolható. A számítás menetének részletezésétől eltekintve a keletkező metán mennyisége az alábbi összefüggéssel határozható meg [3]:

$$
V_{C_{4}}=0,35 \cdot\left(K O I_{b e}-K O I_{k i}\right) \cdot Q
$$

ahol, $V_{C_{4}}=$ a keletkezö metán mennyisége $\left[\mathrm{Nm}^{3}\right], \mathrm{Q}=\mathrm{a}$ betáplálás térfogatárama $\left[\mathrm{m}^{3} /\right.$ év $], \mathrm{KOI}_{\mathrm{be}}=$ belépő kémiai oxigénigény $\left[\mathrm{kg} / \mathrm{m}^{3}\right](!),\left(\mathrm{KOI}_{\mathrm{ki}}\right)=$ kilépő kémiai oxigénigény $\left[\mathrm{kg} / \mathrm{m}^{3}\right](!)$, a 0,35 -ös együttható azt fejezi ki, hogy a szerves anyag csak egy hányada bomlik el anaerob körülmények között.

\subsection{A szennyvíz hőtartalmának hasz- nosítása}

A telephelyre beérkező szennyvíz (szv) hőtartalmának kinyerésére történhet:

nyers szv.böl (a kezelési ciklus elején)

tisztitott szv.böl (kezelési ciklus végén)

szv.iszapból (kezelési ciklus végén)

A szennyvíztisztítás folyamán az emberi melléktermékként bekerülő ammóniavegyületek nitráttá történő oxidációjában (nitrifikációban) részt vevő N.somonas és N.bacter baktériumtörzsek szaporodási sebességét Downing határozta meg 1964ben [4] (1. ábra). A Downing által meghatározott összefüggés az alábbi alakban írható fel: 


$$
\mu_{\max }=0,47 \cdot e^{0,098 \cdot(T-15)}
$$

Látható tehát, hogy a baktériumok növekedése, és így a nitrifikáció hatásfoka és ideje a hőmérséklet csökkenésével exponenciálisan csökken. Mivel a szennyvíztisztítás biológia szakasza érzékeny a hőfokváltozásra, így a kezeletlen szennyvíz hőfokát csak korlátozott mértékben - 0,5 K - [5] szabad csökkenteni, míg a kezelt víz hőfoka akár $8 \mathrm{~K}$-nel is csökkenthető. Ha a kezelést követően az iszap rothasztóba kerül, akkor ez újabb érv a tisztítási szakasz elején alkalmazott hőszivattyú ellen, hiszen a rothasztáshoz hőt kell közölnünk az iszappal, annak hőmérsékletét csökkenteni tehát ésszerütlen. Szintén a kezelés előtti hőkinyerés ellen szól az az érv is, hogy a kezelés után a szennyvíz hőmérséklete - a tartózkodási idők miatt - egyenletesebb.

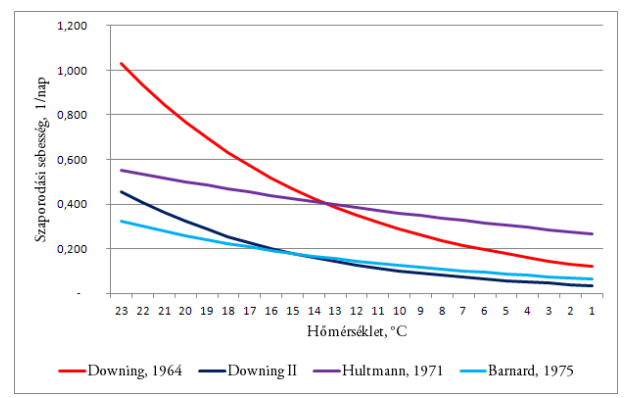

1. ábra $A$ nitrifikáló baktériumok szaporodási sebessége a hömérséklet függvényében

A tisztított szennyvíz tömegárama kevesebb, mint a beérkező tömegáram, hiszen a kezelés során keletkező iszapot és gázokat nem tartalmazza. Az elméletileg kinyerhető hő mennyisége:

$$
Q_{\text {hőszivattyú }}^{i}=c_{i} \cdot m_{i} \cdot \Delta T_{i}
$$

ahol, a $i$ index a nyersvíz esetén $n y$, a tisztított víz esetén $t, c$ a víz fajhője $[\mathrm{kJ} / \mathrm{kgK}], m$ a víz tömege $[\mathrm{kg}]$ és $m_{t}=m_{n y}-m_{\text {iszap }}-$ $m_{g a ́ z o k}$.

\section{Modell}

Az előző fejezetekben szereplő számítások alapján megalkotható a modell, melynek - eredeti célkitüzéseinkkel összhangban - célja a távhőszolgáltatásban felhasznált primer energiahordozó minimalizálása, azaz:

$$
\begin{gathered}
Q_{\text {igény }}=Q_{1}+Q_{2}+Q_{3}+Q_{4} \\
Q_{4} \rightarrow \min .
\end{gathered}
$$

célfüggvény megoldása. Fenti függvény megoldására többféle módszer létezik, egyik praktikus megoldási mód, ha lineáris programozási feladatként tekintjük és valamely ismert algoritmussal (pl. szimplexmódszer) megoldjuk.

\section{Szakirodalmi hivatkozások}

[1] Több ezer ajkai maradhat fütés nélkül, Napi.hu, 2012.12.10.

[2] Tamás J.: Szennyviztisztitás és szennyviziszap elhelyezés, Debreceni Agrártudományi Egyetem, 1998

[3] A szennyviztisztitás alapjai, Szerk: Dr. Kárpáti Árpád, 2007

[4] G. Knowles, A. L. Downing and M. J. Barrett: Determination of Kinetic Constants for Nitrifying Bacteria in Mixed Culture, with the Aid of an Electronic Computer, Water Pollution Research Laboratory, Stevenage, Hertfordshire

[5] Felix Schmid, Sewage Water: Interesting Heat Source For Heat Pumps and Chillers SwissEnergy Agency for Infrastructure Plants, Gessnerallee 38a, CH-8001 Zürich, Switzerland 